MATTHEW D. BUNKER

B. S., Kansas State University, 1979

J. D., University of Kansas, 1985

A REPORT

submitted in partial fulfillment of the requirements of the degree

MASTER OF SCIENCE

Journalism and Mass Communications

KANSAS STATE UNIVERSITY

Manhattan, Kansas

1989

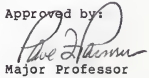


TABLE OF CONTENTS

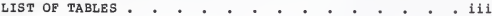

Chapter

1. Introduction . . . . . . . . . . . . 1

2. Review of Literature . . . . . . . . . 4

3. Methodology . . . . . . . . . 12

Method . . . . . . . . . . 12

Analysis of Survey Cases . . . . . . . . 14

4. Results . . . . . . . . . . . 23

Responses to Cases... . . . . . . 23

Characteristics of Respondents . . . . . 28

Responses by Circulation Size . . . . . 29

Responses by Exposure to Litigation . . . 30

Responses by Purchase of Libel Insurance . . 31

Responses by Frequency of Consultation

with Attorney . . . . . . . . . 32

5. Summary Discussion and Conclusion . . . . 34

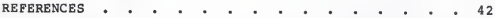

BIBLIOGRAPHY . . . . . . . . . . . . . 43

AP PENDIX

SURVEY QUESTIONNAIRE . . . . . . . . . 45 
TABLES

Table

1. Responses to Cases . . . . . . 24

i i i 
Chapter 1

INTRODUCTION

Libel litigation is a growing threat to the media. Both the number of 1 ibel cases filed and the amount of jury awards have escalated in recent years (Smolla, 1983, p. 4).

In many cases, these lawsuits might have been prevented in the editorial process. Thus, one might assert that editorial awareness and caution can help keep media defendants out of court and avert the problem. On the other hand, too much caution may result in the kind of timid press which the First Amendment freedom of the press guarantee was designed to prevent. If editors see libel problems at every turn and delete all material that might offend a potential plaintiff, our society might well end up with newspapers containing very little news of any importance.

It is apparent that some balance must be struck. Editors must not only recognize libel when they see it, they must also recognize the kinds of material that are protected under our legal system. Embarrassing or offensive material is not necessarily libelous. In a free society, it is sometimes the duty of the press to report unpleasant material, especially concerning the conduct of public officials or those in the public eye. 
The law of libel is complex. It is full of exceptions and contradictions that are confusing to 1 awyers and judges, let alone working journalists. Libel is primarily a creature of the common 1 aw, and, in the past 25 years, a creature of constitutional interpretation. In other words, libel doctrine was not created by Congress or state legislatures. It is judge-made 1 aw, and, as such, is not found in any statute book, but in the hundreds of reported cases of a given jurisdiction. For the layman, even finding, much less comprehending, the relevant caselaw is an impossible task.

Managing editors are in a difficult position. They must recognize and delete potentially libelous passages from stories, yet should not err on the side of caution. The newspaper must not be needlessly exposed to the risks of litigation, but the news must be reported as fully and completely as possible. To make effective decisions concerning what material is or is not published in their newspapers, managing editors must be sufficiently versed in the legal implications of the stories they consider publishing.

This study examined how well managing editors are equipped for this difficult task. Kansas managing editors were presented with eight fact situations. While these fact situations were presented as hypotheticals, each fact situation was derived from reported decisions of the 
Kansas Supreme Court. Each decision constitutes legally valid precedent and thus is "the law" in Kansas. The decisions all deal with some aspect of libel law. By comparing the editors' responses with the decisions of the Kansas Supreme Court, one can determine whether the editors actually understand and can apply $l i b e l$ principles to concrete fact situations -- the kind faced every day by editors. The responses should give some indication of how editors deal with potential libel problems and what areas require special attention by editors, educators and lawyers. 
Chapter 2

\section{REVIEW OF LITERATURE}

\section{Introduction}

In a litigious society such as ours, the quality of news coverage may increasingly depend on the extent to which editors and others making editorial decisions feel free to run stories that contain potentially actionable statements. Thus, editors' perceptions of the law may, in fact, be as important as the so-called "black letter" rules of $1 \mathrm{aw}$.

There seems to be a dearth of research conducted with the aim of determining exactly how editorial decisions are influenced by legal decisions. Numerous communications and legal journals devote space to analyses of the court decisions themselves, but few seem to examine how those making editorial determinations perceive the law made by judicial bodies.

What follows are four leading studies focusing on how editors and other media professionals view the legal climate they face on a daily basis.

The Anderson and Murdock study

According to many legal scholars, the U.S. Supreme 
Court under Warren Burger failed to protect the press to the same extent as its more liberal predecessor, the Warren Court. Douglas A. Anderson and Marianne Murdock (1981) conducted a study to determine how the Burger Court was viewed by newspaper editors. The researchers asked the following questions:

What has been the effect of these decisions on the nation's daily newspapers? Do they think press protection has been eroded by the Court? Are they editorially more conservative when dealing with stories containing potential legal ramifications? How often do the editors consult with attorneys when dealing with legally sticky stories? With the burgeoning number of significant First Amendment cases, where do editors get most of their information about the decisions? To what extent are daily newspapers involved in litigation? (Anderson and Murdock, 1981, p. 526)

The researchers found that 82.5 percent of responding editors (103 of 150 selected from the 1979 Editor and Publisher Yearbook) disagreed with the statement that they were "less aggressive" in deciding whether or not to print potentially libelous passages in stories. However, 74 percent of respondents stated that they were "increasingly careful" when editing stories containing potentially actionable material.

Anderson and Murdock found that 93 percent of editors contact an attorney when faced with potentially libelous material. Larger newspapers (those with circulations of more than 50,000 ) were more likely to be in contact with an attorney concerning questionable material. 
Editors reported a wide variety of sources of information on court decisions. State press association magazines were consulted by 43.7 percent of the respondents, while 59.2 percent received information from wire service newspaper accounts.

Anderson and Murdock reported that a significant number of newspapers responding to the survey had been sued within the five years preceding the survey. Of the larger papers $(50,000$ or greater circulation), 86 percent had been sued, while 41 percent of the smaller newspapers had been sued.

A significant number of the newspapers carried 1 ibel insurance -- 74.8 percent. The authors stated as follows: "Though 57.3\% chose not to reveal the amount of insurance their papers carried, $28.2 \mathrm{~g}$ said it was more than $\$ 1$ million." (Anderson and Murdock, 1981, p. 528)

The Silver and Bow Study

A study by Ben Silver and James Bow (1983) examined the effect of the U.S. Supreme Court case of Herbert $\underline{v}$. Lando (1979) on newspaper managing editors and television news directors. The court in Herbert $\mathrm{v}$. Lando held that libel defendants can be forced to "reveal their thoughts, editorial decisions and newsroom discussions involving the preparation of news stories." (Silver Bow, 1983, p. 115) 
The authors mailed questionnaires to 639 editors and news directors to assess the impact of the Herbert case. The response rate was 48.8 percent. More than half of those responding indicated that the decision was having no effect on either the reporting or editing of news stories.

A small percentage $(9.5$ percent) said the decision was having a "significant effect" on news editing, while 32.5 percent stated the case was having a slight effect. Among the effects noted were greater caution in editing stories and less discussion of storles in the newsroom.

\section{The Kittross Study}

John M. Kittross (1988) studied the effect of recent libel cases on television newsrooms in a paper prepared for presentation at the Broadcast Education Association convention in Las Vegas. Kittross cited cases such as Herbert v. Lando (1979) as causing concern among the media and leading to significant "media bashing."

Kittross stated the justification for his study as follows:

A frequently used emotional argument by media defendants in libel cases is that any increase in number (and notoriety) of cases against the media -- whether or not the plaintiff succeeds -- leads to a socially and politically destructive "chilling effect." The media, perceiving their fiscal vulnerability, thus won't be willing to engage in the 'uninhibited, robust and wide-open' debate on public issues articulated by the U.S. Supreme 
Court in New York Times v. Sullivan ... (Kittross, $1988, \mathrm{p}, 1$ )

The results of the study were reported by market size. For example, in the "100+" market size group, of 41 respondents, six indicated that recent 1 ibel cases had had a "considerable" effect on editing, 24 said the effect was "slight," 11 reported no effect, and none said the effect was "drastic." In the same group, 33 indicated the cases had had no effect on the amount of hard news aired, while the other eight reported the effect was "slight."

An open-ended question asked respondents to characterize the most negative effect of recent 1 ibe 1 decisions. Responses included fear, intimidation, selfcensorship, caution, and conservative tendencies.

The data, however, indicated that such effects are rare and that few of the respondents noticed a pronounced effect on news coverage. The author concluded that if the opinions expressed were genuine, "we are fortunate that most find that the spate of recent cases are having little observable

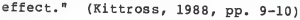

The Anderson, Milner and Galician Study

Douglas A. Anderson, Joe W. Milner and Mary-Lou Galician (1988) conducted a survey of managing editors to determine how the editors viewed the elevation of William 
Rehnquist to chief justice and the appointment of Antonin Scalia to Rehnquist's former position of associate justice of the U.S. Supreme Court. Both of these justices were viewed as constitutional conservatives whose views might have an adverse effect on free-press issues.

of those editors responding, 34 percent agreed that Chief Justice Rehnquist is basically "anti-press freedom," while 32 percent disagreed, and 33 percent indicated they did not know. When asked to respond to the same question regarding Scalia, about one-third agreed, slightly less than one-third disagreed, and 40 percent said they did not know. Nearly all the editors agreed, however, that it is increasingly important for reporters and editors to understand communication 1 aw.

The study examined how frequently editors contacted attorneys about potential legal problems with stories. As might be expected, editors of larger papers maintained more frequent contact with attorneys.

The authors found that about half of the editors reported lawsuits at their newspapers within the five previous years. Eighty-five percent of these suits dealt with 1 ibel.

The study asked editors where they obtained information about media law cases. The most frequent sources of information were state press association magazines, newspaper stories and seminars. 
A number of publications aimed at the professional journalist have carried articles within the last few years emphasizing the seriousness of the libel problem. A recent piece by M. L. Stein (1987) in Editor and publisher discussed the "chilling effect" of libel suits on both the media and insurance carriers. The author stated as follows:
Although noting that editorial personnel and publishers seldom admit they are cowed by libel actions, Klein [a media law attorney] asserted there is a definite 'backing away' from investigative stories by newspapers. (Stein, 1987 , p. 10)

The article discussed one weekly owner who had abandoned investigative journalism in favor of social announcements. The publisher's involvement as a defendant in several libel suits prompted the change in emphasis.

Speaking in 1985, Eugene L. Roberts, Jr. of the Philadelphia Inquirer expressed concern about the current libel climate in the United states. Roberts, delivering the 36 th annul William Allen White Memorial Lecture at the University of Kansas, stated that the escalation of libel suits brought by public figures such as General William Westmoreland and Israeli defense minister Ariel Sharon was an ominous trend: 
[T] he jury verdict in the Sharon case was no victory. And the Westmoreland verdict, whatever it may be, will not be a victory either. The press lost. The public lost. Democracy itself lost, the moment those cases went to trial. (Roberts, 1985, p. 1)

Roberts cited the fact that 19 libel suits had been brought by public officials in the Philadelphia area, including suits by former mayors, judges and legislators. A11 of the plaintiffs, however, were immune from 1 ibel actions regarding statements made in their official capacities.

Roberts also discussed a number of publishers who admitted that the threat of libel suits had forced their newspapers to be more cautious and less willing to tackle sensitive issues. Roberts stated as follows: "This wave of public official litigation that threatens to become a tidal wave is occurring amidst a national climate of unease with the press and with television." (Roberts, 1985, p.7) 


\section{Chapter 3}

\section{METHODOLOGY}

Me thod

A mail questionnaire was sent to all daily newspaper manaing editors in Kansas as listed in the 1987 edition of the Editor and Publisher Yearbook. A cover letter was sent with the questionnaire encouraging recipients to respond and stressing the usefulness of the results to the profession. The first mailing occurred in March 1988. Managing editors who did not respond were contacted by telephone and asked to return the survey. A second mailing occurred in February 1989 to secure responses from editors who had not returned the survey pursuant to the initial mailing and telephone contact.

The questionnaire set forth eight factual situations concerning libel law. The factual situations were taken from the Kansas Reports, the full-text reports of the decisions of the kansas supreme Court. The decisions were final, authoritative declarations of Ransas libel law as applied to the given facts. The cases were chosen to represent important libel precedents with facts of the sort that a manaing editor might frequently be required to consider. To assure the continued validity of the 
decisions, the citations of the cases were checked through Shepard's Citations to be certain that no case had been reversed, overruled or otherwise 1 imited.

From the chosen cases, the decisive facts were presented in eight cases in the survey. All names were changed to prevent the editors from recognizing a given case. Following the presentation of each factual situation, the respondents were asked to decide the issue decided by the Kansas supreme Court.

The survey also obtained the following information: circulation size of the newspaper, sources of media law information used by the editor, previous involvement of the newspaper in libel litigation, libel insur ance coverage, and the extent to which the newspaper relies on attorneys to safeguard against potentially libelous material. 
The first case scenario in the survey read as follows:

The Centerville Telegraph runs an 1 tem announcing the birth of a baby girl to Mr. and Mrs. James Crawford of Centervilie. The announcement also states that the couple have two other children, ages nine and six. Mrs. Crawford is identifiable, as a result of a reference to the names of the grandparents of the child, as Jean Marie Smith. James Crawford files a libel suit against the Telegraph, claiming that he is in fact a bachelor, is not married to Jean Marie, and, furthermore, that Jean Marie is a "woman of ill repute" in the small town who is widely known to have given birth to numerous illegitimate children. Does Crawford have a case?

This question is based on Karrigan v. Valentine (1959). In the Karrigan case, the Kansas supreme court considered whether the suggestion that the plaintiff was married to a woman of 111 repute was libel per se or libel per quod. The defense contended that the birth report was neither and that the plaintiff had no cause of action under these facts.

Libel per se is a form of libel in which the words in question are damaging on their face, without the need to prove extrinsic circumstances demonstrating damage to reputation. Libel per quod consists of words which are not necessarily damaging on their face, but which can become so depending on proof by the plaintiff demonstrating extrinsic facts that make the words damaging to the plaintiff's reputation.

In Karrigan, the Court held that although the birth 
announcement did not constitute libel per se, the

plaintiff's complaint had stated a case of 1 ibel per guod. Thus, the correct answer to the question was "yes."

The second case scenario contained in the survey

stated as follows:

Robert Johnston, a well known local attorney, undertakes to defend Mary Powers, who has been accused of murdering her husband. Contrary to ethical practice, Johnston asks Powers to sign a "contingency fee" agreement. The agreement entitles Johnston to 90 percent of the insurance proceeds from policles on Powers' late husband if she is acquitted. The agreement comes to light and Johnston is censured by the state Board of Law Examiners. A news story in the local paper states that Johnston was censured "for his conduct of the defense" of Powers. The story also states that Johnston "required" Powers to agree to the contingency agreement. Johnston sues for 1 ibe1, claiming that his conduct of the defense was beyond reproach and that Powers voluntarily signed the contingency agreement. Were the statements libelous?

This question is based on steere v. Cupp (1979). In Steere, the Kansas Supreme Court held that the published statements regarding the plaintiff's "conduct of the defense" and the "required" contingency fee agreement were "substantially true." The Court stated as follows:

Steere's censure arose out of his defense of Nellie Schoonover and whether he required her to sign the contingent fee contract or had her sign it or let her sign it, is of no consequence. Appellant [Steere] was the lawyer. It was his duty to know the law and the possible ethical violation. He was responsible for the contract, not Nellie Schoonover. He drafted the instrument, had it 
typed and took it to the jail for Mrs.

Schoonover to sign. Under the circumstances, the use of the word "required" is not out of

line. (Steere v. Cupp, 1979, p. 575)

Thus, while the published statements were perhaps not literally true, the court held that they were close enough to the truth to avoid a finding that they were libelous. The correct answer to question two was "no."

The third question stated as follows:

J. J. Lowery, editor of the Jamestown Journal, publishes an article stating that a rival paper, The Shopper, might soon be changing hands. The article states that the potential new owner, Michael Atwood, would be "all $r$ ight. In fact, anybody would be an improvement on the eunuch who is snorting around in the basement, but unable to do anything else." Although John Crowley, the current owner, wasn't mentioned by name, it is apparent to residents of the area that the statement refers to crowley. Does the statement libel Crowley?

This question was based on Eckert v. Vanpelt (1904). The defendant argued both that the article was not libelous because the plaintiff was not mentioned by name and that the term "eunuch" was not libelous per se because the term carries a secondary meaning connoting weakness or barrenness.

The Kansas Supreme Court disposed of both arguments in upholding the trial court's verdict of $\$ 700$ for the plaintiff. The Court stated that even though the article did not contain the plaintiff's name, Kansas law only required that he show at the trial that the words were 
intended to apply to $\mathrm{him}$ and that the public understood the words to refer to him. The Court also held that the "primary and general definition" of the word eunuch is "a castrated male of the human species." (Eckert v. VanPelt, 1904 , p. 360) Thus, when the word is considered in its ordinary sense, it is libelous per se because it exposes the plaintiff to public hatred, contempt or ridicule. The correct answer to the question was "yes."

The fourth survey question stated as follows:

John Law was a local Blue City lawyer who became the subject of a disbarment proceeding. As is usual in such cases, the Kansas Supreme Court appointed a commissioner to hear the facts and write a report on his or her findings and conclusions in the case. The Blue City Gazateer obtained a copy of the commissioner's report and summarized it in a news story. The headiline of the story stated: "Pindings by supreme Court." Law sued, claiming the headline was itbelous. The body of the story made it clear that it was the Commissioner's report that was being summarized. Can Law recover?

The question was based on the case of Little v. Allen (1939). The main issue before the Court was whether an allegedly libelous inaccuracy in a headine could be "redeemed" by accurate information in the body of the story. The Court took the view that while headines themselves, if sufficiently misleading, can be libelous, in general, headlines "are designed to do no more than to direct the attention of the reader to the article itself." (Little v. Allen, 1939, pp. 415-416) 
The Court held that headines and body copy must be considered as a whole. In Little, the Court said, "no one reading the headines and the article would be misled by the slightly innaccurate statement in the headlines." (Little v. Allen, 1939, p. 416) As a result, the Court upheld the trial court's decision in favor of the defendant. The correct answer to the question was "no."

The fifth survey question stated as follows:

Jan Chaffee is an officer of Fly-By-Night Construction, a Kansas corporation engaged primarily in home remodeling work. The local newspaper reports that the corporation "is locally regarded with disfavor and distrust, and as a get-rich-quick scheme." The paper also reports that a state banking examiner called the corporation "a paper concern." Chaffee files suit, alleging that the paper has libeled her. Can she recover?

Schreiber V. Gunby (1910) provided the basis for this question. Although the case dealt with several different issues and counts raised by the plaintiffs, the crucial holding for these purposes is that the plaintiffs, officers of the corporation, were held to have no personal cause of action against the defendant for statements referring to the company as a corporation -- a separate legal entity. In other words, the corporation had its own legal existence separate from its officers, and a statement that might harm the corporate reputation gave no personal cause of action to its officers. The correct answer to the question was "no." 
The sixth survey question stated as follows:

Robert Crosly was a candidate for re-election to the Kansas Senate. During his first term, Crosly supported a bill reducing possession of marijuana to an unclassified misdemeanor with a maximum penalty of $\$ 100$ for the first offense. Crosly also supported a bill repealing criminal penalties for sodomy between consenting adults. During the election, the local newspaper $r$ an an editorial stating that crosly favored "pot" and "gays." The editorial also stated that Crosly wanted to "de-criminalize" marijuana and "legalize" homosexuality. The editorial cited the Biblical story of Sodom and Gomorrah and quoted drug addicts who claimed they got their start on marijuana. Crosly sues for libel. Can he recover?

This question was based on Hein v. Lacy (1980). The Hein case actually involved publication in a brochure by a political opponent of the plaintiff rather than publication in a newspaper. Nonetheless, the applicable libel doctrines remain the same.

The Kansas Supreme Court held that the trial court had acted correctly in granting sumary judgment to the defendant. The Court found that the brochure's statements that the plaintiff had voted to "decriminalize" marijuana and "legalize" homosexuality were substantially true, in that the plaintiff had voted for bills that would have reduced penalties for possession of marijuana and repealed criminal sanctions in cases of sodomy between consenting adults. The Court stated as follows: 
On the basis of the undisputed factual circumstances contained in the record, we hold that the statements made in the defendant's letter were substantially true. However, it should be added that the whole truth was not stated. It seldom is in political campaigns. (Hein v. Lacy, 1980, pp. 262-263)

The Court also stated the principle that a public official seeking reelection cannot, as a general rule, successfully maintain a libel action. Citing such cases as Coleman v. MacLennan (1908) and New York Times Co. v. Sullivan (1967), the court made it clear that public officials have a difficult burden to meet in defamation actions (the actual malice rule) and that the plaintiff at bar had not met that burden. The correct answer to the question was "no."

The seventh survey question stated as follows:

Jane Harper was a candidate for a seat on the Hooterville City Commission. Harper finished last in the election. The day after the election, the Hooterville chronicle $r$ an a story detailing Harper's losing campaign strategy, which emphasized absentee ballots from nursing homes. The story also discussed Harper's poor employment record, failed attempts to initiate recall actions against city officials, and recent retirement as a controversial police official. In the ensuing libel suit, the Chronicle based its defense on Harper's status as a "public figure." As a "public figure," Harper would have to prove that the story was published with actual malice in order to win the lawsuit. Harper argued that, following the election, she was no longer a "public figure." After the election, Harper asserted, she was no longer voluntarily thrusting herself into public affairs. Is Harper legally a public figure? 
This question was based on Redmond v. Sun publishing Co. (1986). The Kansas Supreme Court held that once the plaintiff became a candidate for public office, he was a public figure for all purposes. The Court stated that because the article came only one day after the plaintiff's unsuccessful bid for office, the facts concerning both the plaintiff's past and his failed campaign were "of public concern. Once these facts entered the public domain, they remained there and subjected Redmond to comments as a public figure." (Redmond v. Sun Publishing Co., 1986, p. 35) As a result, the actual malice rule applied. The correct answer to the question was "yes."

The eighth question in the survey stated as follows:

Mark Sheridan was accused of a triple murder in Blue City, Kansas. The Blue City Beacon wrote a sensational account of the events surrounding the charge. The Beacon referred to Sheridan as the "Killer Who Came Straight From Hell," although Sheridan had not been found guilty at the time the story was printed. Sheridan was subsequentiy convicted of the murders. Prior to his conviction, Sheridan filed a libel suit against the Beacon. Among other defenses, the Beacon claimed that Sheridan was a "public figure" who must prove actual malice on the part of the Beacon. Among the factors the Beacon cited to support its position that sheridan was a public figure were: (1) Intense media coverage of the murder investigation and 1 ts eventual focus on Sheridan; (2) Sheridan's voluntary act of turning himself in to police, seeking protective custody; and (3) Sheridan's arrest and indictment for the crimes. Sheridan argued that he didn't 
voluntarily thrust himself into the forefront of the controversy. Is Sheridan legally a public figure?

This question was based on Ruebke $\underline{v}$. Globe Communications Corp. (1987). In Ruebke, the actual publication of the story was in "startling Detective" magazine $r$ ather than a local newspaper. Citing the three factors mentioned in the survey question, the Kansas Supreme Court stated that although no one factor by itself would have been sufficient to confer the status of "public figure" on the plaintiff, when taken together these factors were enough to confer that status.

The Court stated that public figure status is not a matter of choice, but rather "the result of acts or events which by their nature are bound to invite comment." (Ruebke v. Globe Communications Corp., 1987, p. 601) The correct answer to the question was "yes." 
Chapter 4

\section{RESULTS}

Thirty-two of 46 managing editors returned the survey, resulting in a 70 percent return rate. Since the study functioned as a census of the entire population of Kansas daily managing editors, no resort to statistical techniques is necessary.

\section{Responses to Cases}

A majority of responding editors answered six of the eight cases correctly, with those majorities ranging from near unanimity to close divisions.

In Case \#1, a majority of editors failed to correctly apply a Ransas Supreme Court libel decision. The case involved an erroneous birth announcement. The individual identified as the father of the child claimed he had been libeled by the ldentification because he was not married to the mother of the child, who was widely regarded as a woman of 111 repute. Thirty-one percent of the respondents correctly responded that the plaintiff had a case. Sixtynine percent of responding editors indicated that the plaintiff did not have a case. The Kansas supreme Court in fact held that the announcement was $1 \mathrm{ibelous.}$

Case \#2 concerned an attorney who sued the local 
Table 1

Responses to Cases

\begin{tabular}{lrr}
\hline Case number & Yes & No \\
\hline 1. & $* 318$ & 698 \\
2. & 418 & $\star 598$ \\
3. & $* 778$ & 238 \\
4. & 238 & $* 778$ \\
5. & 558 & $* 458$ \\
6. & 78 & $* 938$ \\
7. & $* 908$ & 108 \\
8. & $* 638$ & 378 \\
\hline
\end{tabular}

*Denotes correct response 
newspaper for a story that dealt with his discipline by the State Board of Law Examiners. The story, while basically true, contained certain phrases that the attorney claimed inaccurately characterized the nature of the disciplinary case. A majority of editors (59 percent) correctly responded that the statements were not libelous. The Kansas Supreme Court had held that the statements, while perhaps not entirely accurate, were nevertheless "substantially true." A large minority (41 percent) believed the statements were libelous.

In case $\$ 3$, a larger majority of respondents reached the correct conclusion. The case dealt with a newspaper editor who referred to a competitor as a "eunuch." Seventy-seven percent of the editors agreed that the statement was libelous. The Ransas Supreme Court had held that "eunuch," in the commonly held definition of the term, was libelous per se because it exposed the plaintiff to contempt and ridicule. Twenty-three percent of the editors concluded that the words were not libelous.

Case 4 involved a misleading headline. The subject of a disbarment proceeding sued a newspaper that correctly reported the conclusions of a commissioner appointed by the Kansas Supreme Court to look into the lawyer's professional conduct. While the body of the story made it clear that the report was issued by the commissioner, the headline indicated that the report was the findings of the supreme 
Court. In deciding the libel case, the Kansas supreme Court held that slight inaccuracies in headlines are not actionable if, by reading the body of the story, the reader would not be misled. Seventy-seven percent of the editors responded in agreement with the court that the lawyer could not recover for the inaccurate headine. A minority $(23$ percent) of respondents concluded that recovery was possible under the facts of this case.

Case $\$ 5$ dealt with whether an officer of a corporation could recover for a statement that potentially libeled the corporation but which did not personally libel the officer. The Kansas Supreme Court distinguished between a personal cause of action by the officer and the reputational interests of the corporation -- a separate legal entity. A slight majority of editors (55 percent) responded that the officer could recover, a result contrary to that reached by the court. A sizable minority (45 percent) indicated that the officer could not recover.

In Case \#6, an overwhelming majority of respondents answered the scenario correctly. Ninety-three percent of the editors correctly concluded that the plaintiff in the case could not recover for a newspaper editorial accusing a candidate for state political office of supporting "pot" and "gays." The editorial, while perhaps characterizing the politician's record in a rather unfair manner, nevertheless contained basically factual information about 
the candidate's stands on certain issues. The Kansas Supreme Court, along with the majority of respondents, concluded that the candidate could not recover. The court's rationale involved both the substantial truth of the statements and the wide latitude accorded discussions of public figures.

Case $\# 7$ raised the issue of the duration of public figure status. The plaintiff, a recent candidate for public office, maintained that she was no longer a public figure after the election, which she lost. The news story in question was printed the day after the election. The Kansas supreme Court held that a public figure doesn't immediately return to private figure status. Most of the editors also reached that conclusion. Ninety percent of respondents indicated that the plaintiff was still a public figure when the story was printed. However, 10 percent apparently felt that public figure status, and the associated higher degree of protection accorded defendants, vanishes immediately after the event that produced that status ends.

Case $\$ 8$ involved the public figure status of an individual who had been charged with a sensational murder but not yet convicted. The Ransas supreme Court held that the plaintiff was a public figure, citing three factors that were set out in the case. A majority (63 percent) of editors also concluded that the plaintiff should be 
considered a public figure, but a sizable minority (37 percent) disagreed.

Characteristics of Respondents

As might be expected in a sparsely populated state such as Ransas, most of the editors worked on smaller circulation newspapers. The majority (53 percent) worked for papers with less than 7,500 circulation. The next largest group ( 31 percent) were associated with papers with circulations between 7,500 and 14,999 . Six percent of the editors' newspapers fell into the 15,000 to 29,999 category and 9 percent had circulations of 30,000 or more.

The question concerning sources of information on media law allowed multiple responses. Forty-two percent of respondents said they received media law information from seminars, while 39 percent received information from state press assoctation magazines. Miscellaneous media law magazines provided information to 32 percent of editors, with 26 percent deriving information from wire service newspaper accounts of legal developments. Twenty-six percent of respondents chose "other," indicating such sources as media law texts and handbooks, newsletters, lawyer's opinions, universtty training, and in-house corporate advisories.

Only 16 percent of editors' papers had been sued for 
libel within the five years preceding the survey. Nonetheless, a sizêable majority ( 82 percent) of the respondents' newspapers carried libel insurance.

Most of the respondents' papers had some contact with an attorney concerning potentially libelous material. Only 16 percent indicated they checked questionable stories or passages with an attorney once a month or more often, but 97 percent checked such material with an attorney prior to publication at some less-frequent interval. Only two respondents indicated their employers had in-house counsel, but 78 percent of the respondents' papers kept an attorney on retainer.

Responses by Circulation Size

Cross-tabulating the editors' responses to the cases with demographic information on the editors' newspapers demonstrated some interesting trends. Overall, the size of the newspaper did not affect the correctness of the responses. However, certain cases revealed differences between circulation sizes. For example, on case \#4, involving the inaccurate headline, editors from the smallest circulation papers did not perform as well as editors from larger circulation papers. Sixty-nine percent of editors from papers with circulations of less than 7,500 correctly responded that the inaccurate headine was not libelous, while 89 percent of editors from papers with 
circulations of 7,500 to 14,999 chose the correct response. All three of the respondents in the 30,000 or more circulation category correctly answered case \#4.

This pattern was reversed on case $\# 8$, where the issue was whether a criminal defendant was a public figure. Eighty-one percent of editors from the smallest circulation group $(7,500$ or less) correctly responded that the accused party was a public figure. Only 44 percent of the editors in the next-largest circulation size group $(7,500$ to $14,999)$ chose the correct response. In the largest group $(30,000$ or more), only one respondent, out of a total of three in the group, chose the correct response.

Responses by Exposure to Litigation

There was considerable variance in responses between editors whose newspapers had been sued within the past five years and those whose papers had not been sued. Sixty percent of editors whose papers had been sued within the five years preceding the survey correctly responded to case \$1, involving the misidentification of a father in a birth announcement. Only 26 percent of editors whose papers had not been sued within five years correctly recognized that the plaintiff had a cause of action.

On case $\$ 2$, involving substantially true statements about the discipline of an attorney, only 40 percent of the group that had been sued correctly answered that the 
statements were not libelous, while 65 percent of the group that had not been sued answered the case correctly.

The editors whose papers had been sued did substantially better on case $\# 3$, concerning the actionability of the word "eunuch." One hundred percent of the group that had been sued correctly recognized that the word was libelous, while only 71 percent of the group that had not been sued within five years responded correctly. These two groups also responded differently to case \#8, dealing with the public figure status of a criminal defendant. Only 40 percent of the group that had been sued responded that the accused was a public figure, while 67 percent of the group that had not been sued responded correctly that he was a public figure.

\section{Responses by Purchase of Libel Insurance}

Substantial differences also existed between the responses of those who indicated their paper carried 1 ibel insurance and editors whose papers did not, although the latter group consisted of only four respondents. Although only forty-three percent of the group with insurance recognized the actionability of the erroneous birth announcement in case $\$ 1$, none of the non-insured group correctly answered this case.

The second case also demonstrated wide disparities between these groups. Here all the members of the non- 
insured group responded that the statements about the attorney's descipline were not libelous, as indeed the Kansas Supreme Court determined. Only 57 percent of the insured group answered this case correctly.

The insured group performed substantially better on case $\# 7$, in which a candidate for public office was found to be a public figure the day after the election. Ninety-five percent of the insured group responded that the candidate was legally a public figure, while only 75 percent of the non-insured group chose this response.

Reponses by Frequency of Consultation with Attorney

There also were differences in the responses of those who indicated that they conferred with an attorney concerning potentially libelous stories at least once per month and those who responded that they did not check stories as of ten. Eighty percent of those who consulted with an attorney once per month or more often correctly responded that the statements regarding the discipline of an attorney in case \#2 were not libelous. Only 54 percent of respondents in the other group answered this question correctly.

The group that consulted with an attorney less frequently performed better than the more frequent group on case $\# 3$, in which the correct response recognized the actionability of the word "eunuch." Eighty percent of the less frequent group responded that the statement was 
libelous, while only 60 percent of those who consulted with an attorney at least once per month recognized the statement as 1 ibelous.

These two groups also exhibited substantially

different outlooks on case \#8, which dealt with the public figure status of a criminal defendant. Seventy-two percent of the group that consulted less frequently correctly responded that the individual in question was a public figure, while only 20 percent of the more frequent group answered the case correctly. 


\section{Chapter 5}

\section{SUMMARY DISCUSSION AND CONCLUSION}

On the whole, the editors who responded to the survey demonstrated an awareness of libel law. A majority of editors responded correctly to six of the eight cases in the survey. A number of the cases presented difficult legal issues that could not be resolved with a superficial knowledge of the subject. However, the study points out the need for greater legal sophistication in dealing with certain issues.

Cases \#1 and \#5 were the two cases which a majority of respondents answered incorrectly. The responses to case \#1 -- the erroneous birth announcement -- suggest that most editors did not recognize the danger of misidentification in a context that, viewed in isolation, seems relatively innocuous. The crucial point seems to be that any misidentification is potentially actionable if the surrounding circumstances, which may be unknown to editors at the time of publication, subject the misidentified individual to ridicule or contempt. The responses to case \#1 suggest that Kansas editors may need to become more aware of how crucial accuracy is, even in seemingly routine sections of the newspaper, such as birth announcements.

Case 5 , the other case answered incorrectly by a 
majority of editors, dealt with a corporation's interest in reputation. The kansas supreme Court concluded that an officer of a corporation may not bring a libel action for statements that libel the corporation rather than the officer personally. Those surveyed may not have recognized that distinction. Nevertheless, editors need to become more aware of the separate legal status of individuals versus corporations.

Case \#2, involving slight inaccuracies in a report of attorney misconduct, was answered correctly by only a slight majority of the editors ( 59 percent), even though the Kansas Supreme Court concluded on the same facts that the report was "substantially true." The responses suggest an attitude of caution among editors that may not be warranted. Likewise, 23 percent of those responding to case $\$ 4$ seemed unaware of the rule that headlines must be read with the story when questions of 1 ibel arise.

Responses to both of these cases suggest that editors may be operating without an awareness of the latitude available to them in reporting potentially libelous stories, such as these two dealing with disciplinary actions against attorneys.

Most editors were aware that calling a man a "eunuch," as discussed in case \#3, is libelous. However, a minority apparently was unaware that simple "name calling" can be actionable, particularly, as here, when it suggests 
some personal defect that would cause harm to the plaintiff's reputation.

The last three cases -- \#6, \#7, and \#8-- all dealt at least to some degree with the issue of the enhanced protection accorded media defendants when writing about public figures and public officials. The fact that the majority of editors answered all three questions correctly might be explained in part by the sheer volume of discussion generated by New York Times v. Sullivan (1964) and its progeny. Most newspaper professionals have probably read and heard more about this area of media law than any other.

Aside from the basic truthfulness of the statements made about the candidate for state office in case *6, the fact that the overwhelming majority of editors ( 93 percent) correctly recognized that the plaintiff could not recover suggests that the editors were aware of the special status of those who seek public office.

Ninety percent of respondents also recognized that public figure status does not end the day after the election -- the issue in case $\$ 8$. Again, this suggests that the basic ideas contained in Sullivan and its progeny are widely known among Kansas editors.

Case \#8 presented a more challenging application of the public figure doctrine -- the issue of the status of a criminal defendant who has not yet been convicted of any 
crime. A smaller percentage of editors (63 percent) were able to reach the correct conclusion that the criminal defendant was a public figure, despite little in the way of "voluntary" conduct on his part. The responses suggest that quite a number of editors may not be aware of the enhanced protection provided by this decision in certain circumstances.

Cross-tabulating the data revealed cases on which certain subgroups of editors were quite divided. While circulation size of the papers did not seem to be a valid predictor of legal knowledge, certain trends are observable. About half the cases $(\# 2, \# 4, \# 7$, and \#8) were cases in which a correct answer required the editor to respond that statements were not 1 ibelous or that an individual was a public figure. These cases, which might be referred to as "caution" cases, essentially require an editor to determine that it is legally safe to use the material in question, even though an editor attuned to libel problems might be reluctant to do so. This reluctance is enhanced in an informed editor who is aware of large judgments recovered against newspapers for seemingly minor errors.

Editors of larger papers seemed to demonstrate this caution in their responses to case \#8, in which a criminal defendant was held to be a public figure. This status would allow wider latitude for errors on the part of the 
publication. Eighty-one percent of the smallest circulation group (less than 7,500) correctly responded that the plaintiff was a public figure. The larger circulation groups seemed to exhibit much greater caution, with only 44 percent of the 7,500 to 14,999 group answering the case correctly. In the largest circulation group $(30,000$ or more) only one respondent of the group of three editors responded correctly.

This apparent caution is also exhibited in the group of respondents whose newspapers had been sued within the five years preceding the survey. Sixty percent of this group recognized the libelous birth announcement in case one, while only 26 percent of the group that had not been sued within five years answered the case correctly. Case \#2, a "caution" case involving somewhat inaccurate but non-libelous statements about the discipline of an attorney, generated correct responses by 65 percent of the group that had not been sued, but only 40 percent of the sued group responded correctly. Although the statements were held to be protected, the group that had been subjected to litigation chose the cautious, although incorrect, response.

The differences in these two groups also seems to be demonstrated in the responses to case $\# 3$, in which "eunuch" was held to be libelous. One hundred percent of the group that had been sued recognized the existence of 
libel, while only 71 percent of the other group responded correctly. Likewise, in the responses to case \#8, caution seemed to hold sway among the group that had been sued. Forty percent of that group responded that the criminal defendant in question was a public figure, while 67 percent of the group that had not been sued correctly responded that the accused was a public figure.

Caution also may be a factor in differences between those editors whose papers had libel insurance and those whose papers were uninsured. Forty-three percent of the insured group spotted the actionability of the misidentified $f$ ather in case $\# 1$, while none of the four respondents in the uninsured group responded correctly. By contrast, case \#2, a "caution case" involving non-1ibelous statements about an attorney, produced correct answers by all four of the uninsured group and only 57 percent of the insured editors.

One group of editors in whom awareness of libel did not invariably lead to an overcautious approach to the cases was the group of editors who checked potentially libelous material with an attorney once a month or more often. Eighty percent of these editors answered case $\$ 2$ correctly, while only 54 percent of the editors who did not check with an attorney as frequently answered the case correctly. 
The group that sought advice frequently also performed better on case \#7, involving a politician's status as a public figure the day after the election. One hundred percent of the more frequent group correctly responded that the plaintiff was a public figure, while 88 percent of the group that sought advice less frequently responded correctly.

Caution seemed to reappear, however, in the responses to case $\#$. Only 20 percent of the editors who counseled with an attorney more frequently correctly recognized that the criminal defendant in question was a public figure. Seventy-two percent of the other group responded correctly.

Generally, Kansas editors demonstrated an acceptable grasp of libel law. Certain subgroups demonstrated a wariness toward 1 ibel issues that suggests they may be removing protected material as well as 1 ibelous material when deciding what stories or passages can be published without fear of subsequent legal action. Future studies in this area might focus on other legal issues confronting Kansas editors, such as privacy and liability for emotional distress.

Those editors in the groups that are apparently more libel conscious (larger circulation papers, recent litigation, insured for libel) appear, not surprisingly, to exhibit much greater wariness in approaching potentially 
actionable material. These editors see libel both where it is and where it is not. This finding seems to suggest the existence of the so-called chilling effect among Kansas editors who are more involved with and aware of 1 ibel issues. 
Anderson, D. A., Milner, J. W. Galician, M. (1988). How editors view legal issues and the Rehnquist court. Journalism Quarter $1 y$, 65, 294-298.

Anderson, D. A. \& Murdock, M. (1981). Effects of communication law decisions on daily newspaper editors. Journalism Quarterly, 58, 525-534.

Coleman v. MacLennan, 78 Kan. 711, 98 P. 281 (1908).

Eckert v. VanPelt, 69 Kan. 357, 76 P. 909 (1904).

Hein v. Lacy, 228 Kan. 249, 616 P.2d 277 (1980).

Herbert v. Lando, 441 U.S. 153 (1979).

Karrigan v. Valentine, 184 Kan. 783, 339 P.2d 52 (1959).

Kittross, J. M., (1988, Apri1). Libel decisions and the tv newsroom. Paper presented at the meeting of the Broadcast Education Association, Las Vegas, NV.

Little V. Allen, 149 Kan. 414, 87 P.2d 510 (1939).

New York Times Co. v. Sullivan, 376 U.S. 254 (1964).

Redmond v. Sun Publishing Co., 239 Kan. 30,716 P.2d 168 $(1986)$.

Ruebke $v$. Globe Communications Corp., 241 Kan. 595, 738 P.2d 1246 (1987).

Schreiber v. Gunby, 81 Kan. 459, 106 P. 276 (1910).

Silver, B. \& Bow, J. (1983). Effects of Herbert v. Lando on the news process. Journalism Quarterly, 60, 115-118.

Smolla, R. A. (1983). Let the author beware: The rejuvenation of the American law of libel. University of Pennsylvania Law Review, 132, 1-94.

Steere v. Cupp, 226 Kan. 556, 602 P.2d 1267 (1979).

Stein, M. L. (1987, July 4). The chilling effect. Editor and publisher, pp. 10-11. 


\section{BIBL IOGRAPHY}

Anderson, D. (1975). Libel and press self-censorship. Texas Law Review, 53, 422-481.

Anderson, D. A., Milner, J. W. Galician, M. (1988). How editors view legal issues and the Rehnquist court. Journalism Quarterly, 65, 294-298.

Anderson, D. A. \& Murdock, M. (1981). Effects of communication law decisions on daily newspaper editors. Journalism Quarterly, 58, 525-534.

Coleman V. MacLennan, $78 \mathrm{Kan} .711,98$ P. 281 (1908).

Eaton, J. (1975). The American law of defamation through

Gertz v. Robert Welch, Inc, and beyond: An analytical

primer. Virginia Law Review, 61, 1349-1451.

Franklin, M. A. (1977). The first amendment and the fourth estate. Mineola, N.Y.: Foundation Press.

Eckert V. Vanpelt, 69 Kan. 357, 76 P. 909 (1904).

Hein v. Lacy, 228 Kan. 249, 616 P.2d 277 (1980).

Herbert $\underline{\text { V. Lando, }} 441$ U.S. 153 (1979).

Hill, A. (1976). Defamation and privacy under the first amendment. Columbia Law Review, 76, 1205-1313.

Karrigan V. Valentine, 184 Kan. 783,339 P.2d 52 (1959).

Kittross, J. M., (1988, April). Libel decisions and the tv newsroom. Paper presented at the meeting of the

Broadcast Education Association, Las Vegas, NV.

Little V. Allen, 149 Kan. 414,87 P.2d 510 (1939).

New York Times Co. v. Sullivan, 376 U.S. 254 (1964).

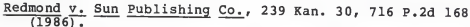

$\frac{\text { Ruebke }}{1246} \frac{\mathrm{v} .}{(1987)} \frac{\text { Globe }}{980 m m u n i c a t i o n s}$ Corp., 241 Kan. 595, 738 P.2d 
Schreiber v. Gunby, 81 Kan. 459, 106 P. 276 (1910).

Silver, B. \& Bow, J. (1983). Effects of Herbert v. Lando on the news process. Journalism Quarter1y, 60, 115-118.

Smolla, R. A. (1983). Let the author beware: The rejuvenation of the American law of 1 ibel. University of Pennsylvania Law Reviewd, 132, 1-94.

Smolla, R. A. (1986). Suing the press. New York: Oxford University Press.

Steere v. Cupp, 226 Kan. 556, 602 P.2d 1267 (1979).

Stein, M. L. (1987, July 4). The chilling effect. Editor Publisher, pp. 10-11.

Wade, J. W. (1977). The communicative torts of the first amendment. Mississippi Law Journal, 48, 671-711. 


\section{DIRECTIONS}

We are interested in your opinions concerning Kansas libel law. Please answer the following survey to the best of your ability. There are no correct answers and your opinion will be held in the strictest confidence. Listed on the following pages are hypothetical legal cases. We would like your opinion on the legal ramifications of these cases. At the end of the cases is a short questionnaire asking for information about your newspaper.

1. The Centerville Telegraph runs an item announcing the birth of a baby girl to $\mathrm{Mr}$. and Mrs. James Crawford of Centerville. The announcement also states that the couple have two other children, ages nine and six. Mrs. Crawford is identifiable, as a result of a reference to the names of the grandparents of the child, as Jean Marie Smith. James Crawford files a libel suit against the Telegraph, claiming that he is in fact a bachelor, is not married to Jean Marie, and, furthermore, that Jean Marie is a "woman of ill repute" in the small town who is widely known to have given birth to numerous illegitimate children. Does Crawford have a case?

Yes

No

2. Robert Johnston, a well known local attorney, undertakes to defend Mary Powers, who has been accused of murdering her husband. Contrary to ethical practice, Johnston asks Powers to sign a "contingency fee" agreement. The agreement entitles Johnston to $90 \%$ of the insurance proceeds from policies on Powers' late husband if she is acquitted. The agreement comes to 1 ight and Johnston is censured by the state Board of Law Examiners. A news story in the local paper states the Johnston was censured "for his conduct of the defensen of Powers. The story also states that Johnston "required" Powers to agree to the contingency agreement. Johnston sues for libel, claiming that his conduct of the defense was beyond reproach and 
that Powers voluntarily signed the contingency agreement. Were the statements libelous?

Yes

No

3. J.J. Lowery, editor of the Jamestown Journal, publishes an article stating that a rival paper, The Shopper, might soon be changing hands. The article states that the potential new owner, Michael Atwood, would be "all right. In fact, anybody would be an improvement on the eunuch who is snorting around in the basement, but unable to do anything else." Although John Crowley, the current owner, wasn't mentioned by name, it is apparent to residents of the area that the statement refers to Crowley. Does the statement libel Crowley?

Yes

No

4. John Law was a local Blue City lawyer who became the subject of a disbarment proceeding. As is usual in such cases, the Kansas Supreme Court appointed a commissioner to hear the facts and write a report on his or her findings and conclusions in the case. The Blue City Gazateer obtained a copy of the commissioner's report and summarized it in a news story. The headline of the story stated: "Findings by Supreme Court." Law sued, claiming the headline was libelous. The body of the story made it clear that it was the commissioner's report that was being summarized. Can Law recover?

Yes

No

5. Jan Chaffee is an officer of FlY-BY-Night Construction, a Ransas corporation engaged primarily in home remodeling work. The local newspaper reports that the corporation "is locally regarded with disfavor and distrust, and as a getrich-quick scheme." The paper also reports that a state banking examiner called the corporation "a paper concern." 
Chaffee files suit, alleging that the paper has libeled her. Can she recover?

Yes

No

6. Robert Crosly was a candidate for re-election to the Kansas Senate. During his first term, Crosly has supported a bill reducing possession of marijuana to an unclassified misdemeanor with a maximum penalty of $\$ 100$ for the first offense. Crosly also supported a bill repealing criminal penalties for sodomy between consenting adults. During the election, the local newspaper $r$ an an editorial stating the Crosly favored "pot" and "gays." The editorial also stated that Crosly wanted to "decriminalize" marijuana and "legalize" homosexuality. The editorial cited the Biblical story of Sodom and Gomorrah and quoted drug addicts who claimed they got their start on marijuana. Crosly sues for 1ibel. Can he recover?

Yes

No

7. Jane Harper was a candidate for a seat on the Hooterville City Commission. Harper finished last in the election. The day after the election, the Hooterville Chronicle ran a story detailing Harper's losing campaign strategy, which emphasized absentee ballots from nursing homes. The story also discussed Harper's poor employment record, failed attempts to initiate recall actions against city officials, and recent retirement as a controversial police official. In the ensuing libel suit, the Chronicle based its defense on Harper's status as "public figure." As a "public figure," Harper would have to prove that the story was published with actual malice in order to win the lawsuit. Harper argued that, following the election, she was no longer a "public figure." After the election, Harper asserted, she was no longer voluntarily thrusting herself into public affairs. Is Harper legally a public figure?

Yes

No 
8. Mark Sheridan was accused of a triple murder in Blue City, Ransas. The Blue City Beacon wrote a sensational account of the events surrounding the charge. The Beacon referred to Sheridan as the "Riller Who Came straight From He11," although Sheridan had not been found guilty at the time the story was printed. Sheridan was subsequently convicted of the murders. Prior to his conviction, Sheridan filed a libel suit against the Beacon. Among other defenses, the Beacon claimed that Sheridan was a "public figure" who must prove actual malice on the part of the Beacon. Among the factors the Beacon cited to support its position that Sheridan was a public figure were: Intense media coverage of the murder investigation and its eventual focus on Sheridan; (2) Sheridan's voluntary act of turning himself in to police, seeking protective custody; and (3) Sheridan's arrest and indictment for the crime. Sheridan argued that he didn't voluntarily thrust himself into the forefront of the controversy. Is sheridan legally a public figure?

Yes

No

Please answer the following questions:

1. The circulation of your newspaper is:

less than 7,500

7,500 to 14,999

15,000 to 29,000

30,000 or more

2. From which of the following sources do you receive most of your information about media law?

Seminars on media 1 aw

State press association magazines

Miscellaneous media law magazines

Wire service newspaper accounts other

3. Has your newspaper been sued for libel in the past five years? Yes No

4. Does your newspaper carry libel insurance? Yes No 
5. Do you regularly (once a month or more often) check potentially libelous stories or passages with an attorney before using them? Yes No

6. Do you ever check potentially libelous material with an attorney before publication? Yes

No

7. Does your newspaper have permanent, in-house counsel? Yes

No

8. Does your newspaper keep an attorney on retainer? Yes

No 
APPLICATION OF LIBEL LAW PRINCIPLES BY RANSAS EDITORS

by

MATTHEW D. BUNKER

B. S., Kansas State University, 1979

J. D., University of Kansas, 1985

AN ABSTRACT OF A MASTER'S REPORT

submitted in partial fulfillment of the requirements of the degree

MASTER OF SCIENCE

Journalism and Mass Communications

RANSAS STATE UNIVERSITY

Manhattan, Kansas

1989 


\section{Abstract}

Bunker, M. D., Application of Libel Law Principles by Kansas Bditors.

This study consisted of a survey that asked managing editors of Kansas daily newspapers to apply principles of Iibel 1 aw to cases based on actual Kansas Supreme Court decisions constituting settled law in Kansas. The survey yielded a return rate of 70 percent of all daily managing editors in Kansas based upon listings in the Editor and Publisher Yearbook. Generally, the editors were successful in applying libel principles. A majority of editors answered six of the eight survey cases correctly. Certain subgroups of the respondents, such as those whose newspapers had been sued within the five years preceding the survey, seemed to demonstrate an overcautious approach to the cases, which suggested that awareness of potential Iibel problems may result in a chilling effect on editors. 